\title{
Genetic variations of Turkish bank vole, Myodes glareolus (Mammalia: Rodentia) inferred from mtDNA
}

ARTICLE in MITOCHONDRIAL DNA · NOVEMBER 2015

Impact Factor: $1.21 \cdot$ DOI: 10.3109/19401736.2015.1089537

READS

112

7 AUTHORS, INCLUDING:

Colak Reyhan

Ankara University

42 PUBLICATIONS 169 CITATIONS

SEE PROFILE

Irfan Kandemir

Ankara University

39 PUBLICATIONS 228 CITATIONS

SEE PROFILE

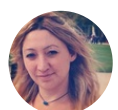

Gül Olgun Karacan

Aksaray Üniversitesi

7 PUBLICATIONS 4 CITATIONS

SEE PROFILE

Johan R Michaux

University of Liège

111 PUBLICATIONS 2,517 CITATIONS

SEE PROFILE 


\section{Genetic variations of Turkish bank vole, Myodes glareolus (Mammalia: Rodentia) inferred from mtDNA}

Reyhan Çolak, Gül Olgun Karacan, Irfan Kandemir, Ercüment Çolak, Teoman Kankiliç, Nuri Yigit \& Johan Michaux

To cite this article: Reyhan Çolak, Gül Olgun Karacan, Irfan Kandemir, Ercüment Çolak, Teoman Kankiliç, Nuri Yigit \& Johan Michaux (2015): Genetic variations of Turkish bank vole, Myodes glareolus (Mammalia: Rodentia) inferred from mtDNA, Mitochondrial DNA, DOI: 10.3109/19401736.2015.1089537

To link to this article: http://dx.doi.org/10.3109/19401736.2015.1089537

曲 Published online: 05 Nov 2015.

Submit your article to this journal $\pi$

Q View related articles ¿

View Crossmark data 


\title{
Genetic variations of Turkish bank vole, Myodes glareolus (Mammalia: Rodentia) inferred from mtDNA
}

\author{
Reyhan Çolak ${ }^{1}$, Gül Olgun Karacan ${ }^{2}$, Irfan Kandemir ${ }^{1}$, Ercüment Çolak ${ }^{1}$, Teoman Kankiliç ${ }^{3}$, Nuri Yigit ${ }^{1}$, and \\ Johan Michaux ${ }^{4}$ \\ ${ }^{1}$ Department of Biology, Faculty of Science, Ankara University, Tandoğan, Ankara, Turkey, ${ }^{2}$ Department of Biology, Faculty of Science and Letters, \\ Aksaray University, Aksaray, Turkey, ${ }^{3}$ Department of Biology, Faculty of Arts and Sciences, Niğde University, Niğde, Turkey, and ${ }^{4}$ Conservation \\ Genetics Unit, Botany Institute (Bat. 22), University of Liège, Liège, Belgium
}

\section{Abstract}

The bank vole, Myodes glareolus, lives in deciduous forests throughout the Palearctic region. In Turkey, this species is distributed only in northern Anatolia (the Black Sea region) where these forests exist. This study reveals genetic differentiation among bank vole populations based on two regions of mitochondrial DNA (cytochrome $b$ and D-loop). Populations in northern Anatolia are divided into two genetic lineages (the "eastern" and "western Black Sea" lineages) by the Kızılırmak Valley. While the western Black Sea lineage is close to the Balkan lineage, in accordance with their geographical proximities, surprisingly, the Uludag lineage, also situated in Western Turkey appears related to the eastern Black Sea population. The divergence time analyses suggest a separation between the Balkan and Turkish groups around 0.26 Mya, whereas the split between the eastern and western Black sea lineages appeared a little bit later $(0.20 \mathrm{Mya})$. Our results suggest that regional refuges existed for this species in Turkey and that small-scale habitat fragmentations led to genetic differentiations between Myodes populations.
\end{abstract}

\section{Keywords}

Cytochrome b, D-loop, Myodes glareolus, mtDNA, Turkey

\section{History}

Received 1 July 2015

Revised 27 August 2015

Accepted 29 August 2015

Published online 30 October 2015

\section{Introduction}

Climatic fluctuations that particularly occurred during the Quaternary period have played a major role in shaping the present geographical distribution of both species and their genetic diversity (Hewitt, 2000, 1996, 1999). Populations were repeatedly isolated during glacial peaks in different refugia, leading to various re-colonization patterns when the climate improved (Taberlet et al., 1998). Most of the studies have indicated that southern Europe, Asia Minor and the Caucasus acted as glacial refugia for taxa that are now widespread (Hewitt, 2000), although some species also persisted in more northern refugia (Kotlik et al., 2006).

One of these southern European refuges correspond to Turkey. This region is characterized by many barriers such as mountains (the Anatolian Diagonal, the Taurus and the Black Sea Mountains) and seaways (the Black Sea, the Aegean and the Mediterranean Seas) (Bilgin, 2011). During thousands of years, these barriers inhibited gene flow among populations of many species and probably led to genetic differentiation within a majority of them. This would explain the high level of endemic species and subspecies living presently in Turkey (Ciplak, 2004, Demirsoy, 2002).

Turkey is also a corridor between Europe and Asia from a biogeographical perspective. This region is therefore particularly interesting to better understand the past relationships among Asian and European species in a phylogeographic perspective.

Correspondence: Reyhan Çolak, Department of Biology, Faculty of Science, Ankara University, Tandoğan, Ankara 06100, Turkey. Tel: +903122126720/1058. E-mail: rcolak@science.ankara.edu.tr
In this context, species having a wide distribution area covering Europe, Asia as well as Turkey are good models to study the role of this region as a refuge. The bank voles, Myodes glareolus is particularly interesting for such purposes.

This species is a small rodent widely distributed in the Western Palearctic region, covering the majority of European regions until the Ural Mountains. It also lives discontinuously in northern Turkey where it is described as a particular subspecies: M glareolus ponticus (Çolak and Kıvanç, 1991, Krystufek \& Vohralik, 2005). In this region, M. glareolus mainly favors the deciduous and homogenous beech forests of the Black Sea (extends along northern Turkey from Bolu to Artvin provinces) and Marmara regions (northwestern Turkey), at altitudes of up to 2000 m (Çolak and Kıvanç, 1991, Çolak et al., 1997, Felten et al., 1971, Neuhauser, 1936, Osborn, 1962).

Deffontaine et al. (2005, 2009) and Kotlik et al. (2006) evidenced the existence of multiple European continental refuges for $M$. glareolus. These refuges are linked to the forest fragmentations, which appeared during the Quaternary glaciations.

The isolation of bank vole populations in these refuges led to the appearance of a complex phylogeographic structure, with at least seven different lineages (Spanish, Italian, Balkan, western European, eastern European, Carpathian and Pyrenean - a lineage that includes the bank voles distribute in a range of mountains called the Pyrenees between France and Spain -). However, till present date, very less information is available concerning the phylogeographic structure of the Turkish populations.

The aims of this study will be therefore to better understand the phylogeography of the bank vole in Turkey and to detect the effect of habitat fragmentation in this region on its genetic diversity. More precisely, we will study the possible role of 
Anatolia as a glacial refuge. To achieve these goals, we will use two variable regions of mitochondrial DNA (mtDNA) (cytochrome $b$ (cytb) and D-loop). Indeed, many recent studies (Filipi et al., 2015; Michaux et al., 2003, 2005) evidenced that these markers are particularly adapted to clarify the taxonomic status, the biogeographic history and the evolution of mammal populations (Avise, 2000, Hewitt, 1996).

\section{Material and methods}

\section{Sample collection}

A total of 36 specimens of Myodes glareolus were collected from 19 Turkish localities for mtDNA analyses (Figure 1). Additionally, 47 cytb sequences and 8 D-loop sequences of bank voles were downloaded from GenBank. Myodes rutilus was used as outgroup. The information concerning the sampling localities as well as the GenBank accession numbers is shown in supplementary material. The locations of the sampling localities are also given in Figure 1.

\section{Laboratory studies}

Total genomic DNA was isolated from kidney tissue according to the cetyltrimethyl ammonium bromide method of Doyle \& Doyle (1991). DNA was quantified using a spectrophotometer (NanoDrop ND-1000 Spectrophotometer, Thermo Scietific, Wilmington, DE). The cytb gene was amplified using the universal primers: L14724 (5'-CGAAGCTTGATATGAAAAAC CATCGTTG-3') and H15915 (5'-GGAATTCATCTC-TCCGGTT TACAAGAC- $3^{\prime}$ ) (Irwin et al., 1991). Amplifications consisted of an initial denaturation at $94^{\circ} \mathrm{C}$ for $5 \mathrm{~min}, 30$ cycles of denaturation at $93{ }^{\circ} \mathrm{C}$ for $1 \mathrm{~min}$, annealing at $50{ }^{\circ} \mathrm{C}$ for $1 \mathrm{~min}$, extension at

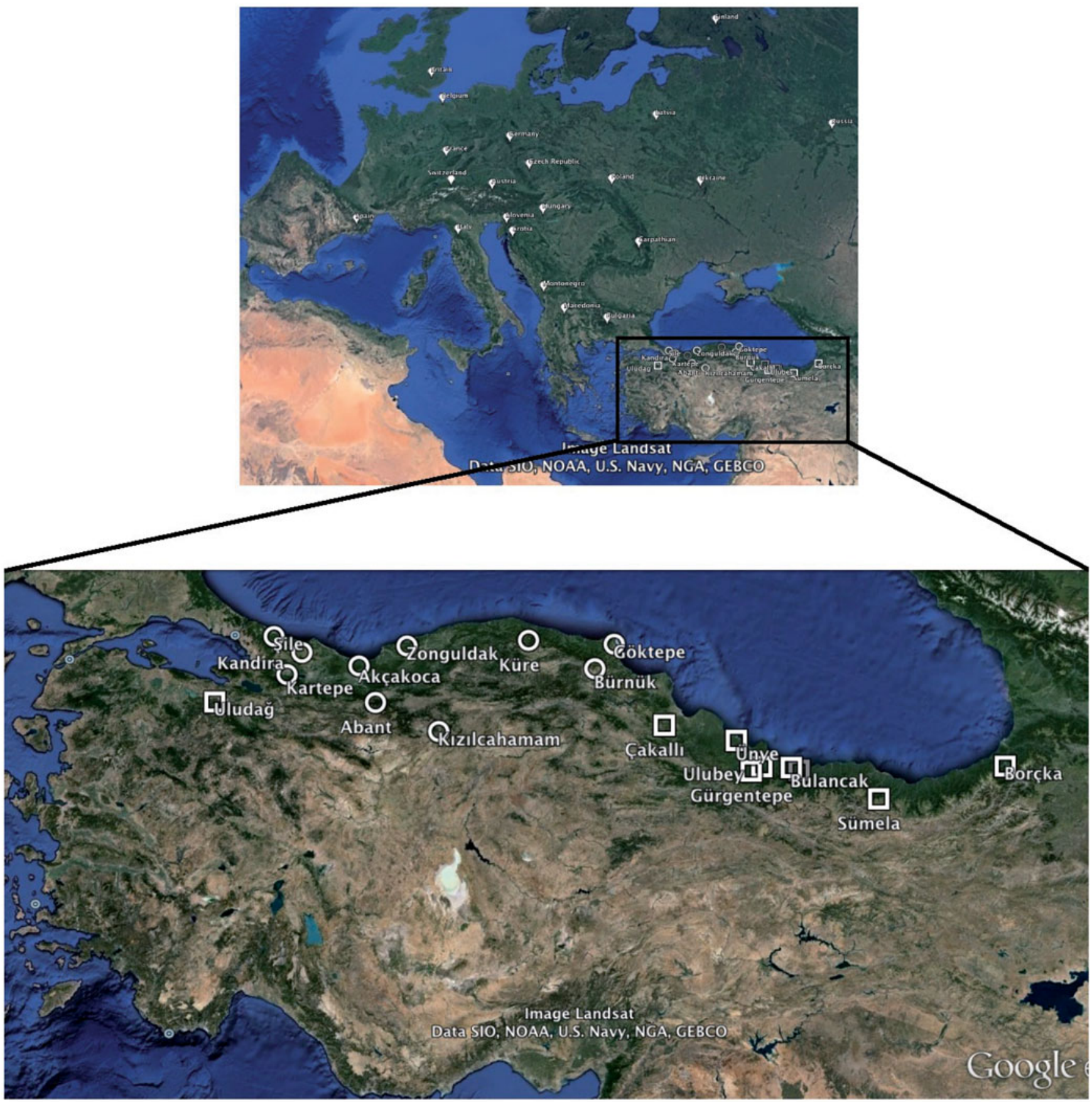

Figure 1. Distribution of the bank vole (Myodes glareolus) sampled in Turkey and the groups revealed by the genetic analyses. O: Western Black Sea Region, $\square$ : Uludag and Eastern Black Sea Region. 
$72{ }^{\circ} \mathrm{C}$ for $5 \mathrm{~min}$, and a $5 \mathrm{~min}$ final extension at $72^{\circ} \mathrm{C}$. Moreover, the control region (D-loop) was amplified using $1 \mathrm{~L}\left(5^{\prime}\right.$ TCCCCACCATCAGCACCCAAAGC- $\left.3^{\prime}\right)$ and $8 \mathrm{H} \quad\left(5^{\prime}-\right.$ GCATTTTCAGTGCTTTGCTTT-ACATAAG- $3^{\prime}$ ) (Matson \& Baker, 2001). Amplifications for D-loop were carried out following the protocol of Matson \& Baker (2001). Amplification reactions were performed in THERMO PX2 thermal cycler (Thermo Fisher Scientific, Waltham, MA). The PCR was run in $25 \mu \mathrm{L}$ of a reaction mixture containing $80 \mathrm{ng}$ of the DNA samples; $10 \times$ reaction buffer $(750 \mathrm{mMTris}-\mathrm{HCl} \mathrm{pH}: 8.8,200 \mathrm{mM}$ $\left(\mathrm{NH}_{4}\right)_{2} \mathrm{SO}_{4}, 0.1 \%$, Tween 20; Thermo); 1.5 units of Taq DNA polymerase (Thermo); $0.2 \mathrm{mM}$ of each deoxynucleotide triphosphate (100 mM of dNTP set solutions, Thermo); $2 \mathrm{mM} \mathrm{MgCl}_{2}$; and 20 pmol of each primer (Thermo).

\section{Phylogenetic analyses}

Phylogeny was constructed both combined analysis of two mtDNA regions and the separate analysis of two mtDNA regions. First, the cytb (972 bp) and D-loop (907 bp) sequences were aligned using Clustal X v.2.1 (Larkin et al., 2007) and BioEdit v.7.1.3 (Hall, 1999). Next, MEGA v. 6 (Tamura et al., 2013) was used to detect the genetic relationships among haplotypes by generating neighbor-joining (NJ), maximum parsimony (MP), and maximum likelihood (ML) trees. The most suitable DNA substitution model for the cytb, D-loop and combined datasets were determined by MEGA v. 6 under the Akaike's information criterion corrected (AICc) as follows: cytb: HKY+G+I, D-loop: GTR $+\mathrm{G}+\mathrm{I}$ and combined data: GTR. NJ analysis was generated using a Kimura 2-parameter (Kimura, 1980). MP analysis was constituted with the tree bisection reconnection (TBR) algorithm. The robustness of the trees was determined by bootstrap resampling (1000 replicates) (Felsenstein, 1985).

To present the phylogenetic construction, we also carried out a Bayesian analysis with MrBayes v 3.1.2 (Huelsenbeck \& Ronquist, 2001) using the best model of nucleotide substitution for combined data found by Modeltest 3.7 (Posada \& Crandall, 1998). The Bayesian tree was conducted for 3.5 million generations, sampling every 1000 and burn-in of $25 \%$.

\section{Population genetics and demographic history}

Polymorphic sites of the sequences obtained from each specimen were screened and specific haplotypes were identified for clades by considering the polymorphism divergence between individuals. In this study, we used haplotypes that were acquired from combined data to detect the relation between specimens using the median-joining method (NETWORK version 4.6; Bandelt et al., (1999)). Analyses of molecular variance (AMOVA) was computed in ARLEQUIN version 3.5 (Excoffier \& Lischer, 2010) to detect the amount of the shared genetic variation within and among the clades in Turkey.

ARLEQUIN version 3.5 (Excoffier \& Lischer, 2010) was also operated to compute the neutrality analysis as Tajima's D (Tajima, 1989), Fu's Fs (Fu, 1997). DnaSP version 5.1 (Rozas, 2009) was used to estimate the haplotype and nucleotide diversities, and the mismatch distributions. MtDNA combined data set was also analyzed in BEAST (Drummond et al., 2012) using a Bayesian skyline plot model to reconstruct changes in population sizes through time. Each major clade was run for Markov Chain Monte Carlo (MCMC) chain lengths of 10 million generations using 2\% evolution rate (Brown et al., 1979).

\section{Divergence dates}

BEAUti was set up to estimate the divergence times between clades using the BEAST v. 1.8.1 (Drummond et al., 2012).
Combined data set of $c y t b$ and D-loop was selected for analysis. GTR substitution model was set applying strict clock under a Yule process of speciation with a random starting tree and the substitution rate was allowed to be estimated. We used the separation time between Eurapean M. glareolus and M. rutilus estimated at 2.5 million years ago (Mya) based on paleontological records as a calibration point (Lebedev et al., 2007). 50 millionMCMC generations were conducted to achieve effective sample sizes (ESS >200), and the results were evaluated by Tracer v 1.6 (Rambaut et al., 2013). The tree files were summarized using TreeAnnotater (Drummond et al., 2012) (Burn-in $=10 \%$ ). The Bayesian tree was visualized and edited using FigTree 1.4 (Rambaut, 2012).

\section{Results}

\section{Pattern of sequence variation}

A total of 73 haplotypes were defined among the 83 bank vole specimens for the $c y t b$ gene, of which 27 were first determined in Turkish populations. Of the $972 \mathrm{bp}$ sequenced, 111 sites were variable and 51 were parsimony-informative. The average ratio of transition/transversion (R) was 6.79 (nucleotide composition was $\mathrm{A}=29.40 \%, \mathrm{~T}=28.00 \%, \mathrm{C}=29.21 \%$, and $\mathrm{G}=13.40 \%$ ).

The alignment of D-loop consisted of 907 nucleotides for 41 haplotypes (33 of which were first determined in Turkish populations), 63 of which were variable and 39 were parsimony-informative. The average ratio of transition/transversion (R) was $3.91 \quad(\mathrm{~A}=31.54 \%, \quad \mathrm{~T}=30.45 \%, \quad \mathrm{C}=25.14 \%, \quad$ and $\mathrm{G}=12.87 \%$ ).

\section{Phylogenetic analyses}

$\mathrm{NJ}, \mathrm{MP}$, and ML analyses of $c y t b$ and $D$-loop were consistent with each other for Turkish groups (Figures S1 and S2). On the other hand, European groups exhibited different topologies, namely that Eastern European group was the base to the rest of the tree in MP and ML trees while there was a single European group in NJ. Also, Balkan lineage was closer to Turkish group and the ItalianSpanish lineage was the base of Balkan and Turkish clades. In this study, Turkish bank voles are separated into two main lineages, respectively, an eastern and a western Black Sea groups even if their robustness is quite weak (BS\% values of $c y t b=24$ for NJ, 38 for MP and 26 for ML; D-loop = 38 for NJ, 35 for MP and 43 for ML). In addition, surprisingly, it is interesting to note that the Uludag sampling locality, situated in the western part of Turkey, is related to the eastern Black Sea lineage even if the bootstrap values for this node is also weak for both $C y t b$ and D-loop trees. Phylogenetic analyses revealed that the Balkan lineage is closer to Turkish lineages as compared to all the other European ones (Italian, Spanish, Western Europe, Eastern Europe, and Basque).

The Bayesian tree of combined data is presented in Figure 2. The two main clades of Turkish specimens (western and eastern Black Sea) appear again, and Uludag specimens are grouped with the eastern Black Sea lineage.

\section{Demographic analyses}

Tajima's D and Fu's Fs values were calculated to evaluate the demographic history of the observed Turkish lineages. Based on combined data analysis, Fu's Fs values indicated population expansion of the western and eastern Black Sea lineages and Turkish lineages together. Even all of the lineages had negative values for Tajima's D indicating population expansion; the results were not statistically significant $(p>0.05)$ (Table 1$)$. In contrast to Fs values of major clades, mismatch analyses obtained from the combined data gave a signal that indicated either a population in demographic equilibrium or a population bottleneck (Figure 3). 


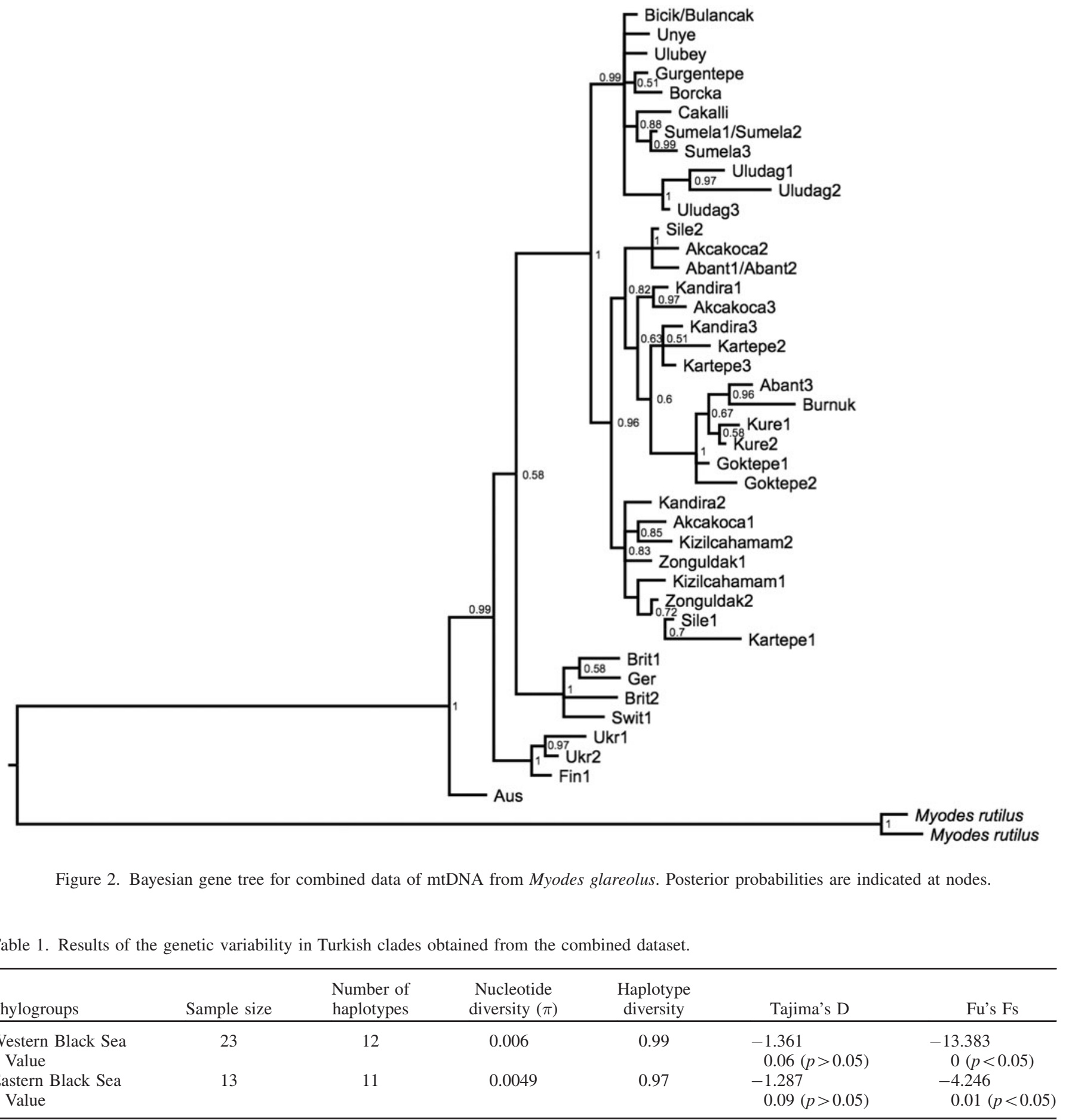

According to the Bayesian skyline plot results, the western and eastern Black Sea clades show population stability rather than growth (Figure 4).

It was not possible to perform mismatch distribution and BSP analyses on the Uludag group as the sampling size was too low for it (4 individuals for $c y t b$ and 3 for $D$-loop). So this group was evaluated with the eastern Black Sea lineage that was close to Uludag group in phylogenetic analyses.

The median-joining networks constructed using the haplotype datasets of the mitochondrial data, supported the phylogenetic analyses. The network evidenced that the eastern and western Black Sea lineages are separated from each other and that the Uludag lineage is close to the eastern Black Sea lineage
(Figure 5). The network also confirms the nucleotide differentiations between the western Turkish lineage and the European populations.

AMOVA results attributed nearly $64 \%$ of mitochondrial variation (combined data of $c y t b$ and $D$-loop) to within groups while nearly $36 \%$ to among groups revealing that the distinction of the western and eastern Black Sea groups was not so strong (Table 2).

\section{Divergence time}

Separation times of European M. glareolus and M. rutilus were applied to the different dichotomies within M. glareolus. Thus, 

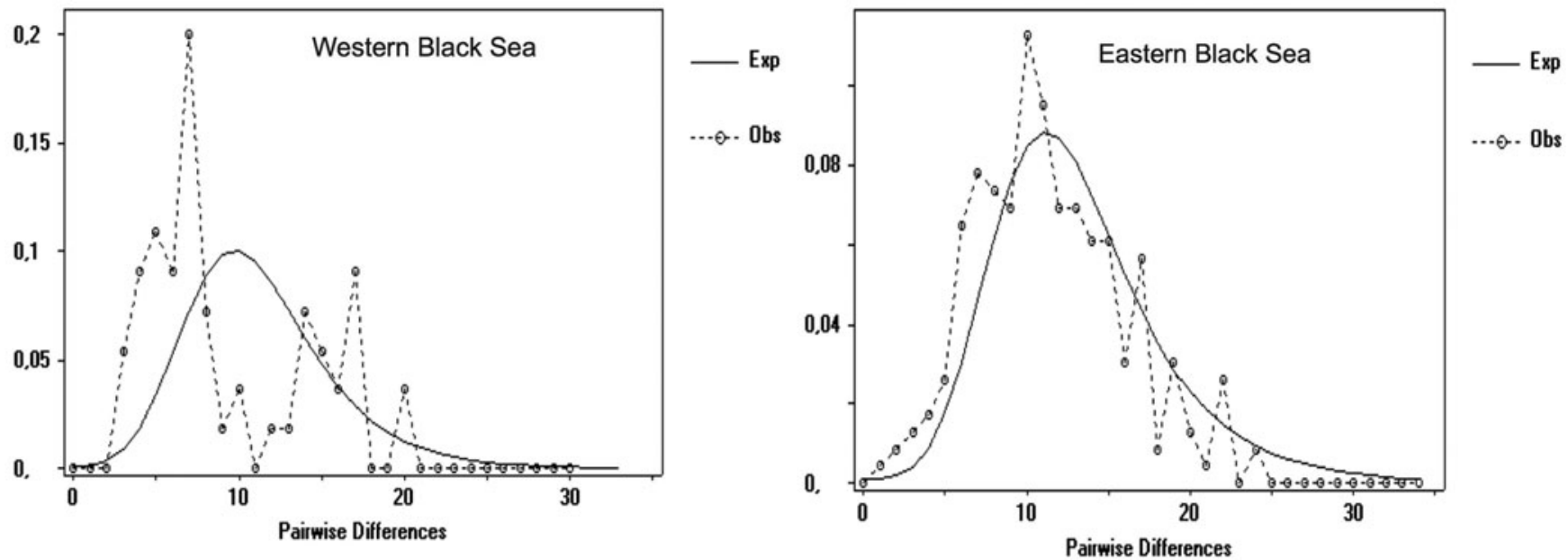

Figure 3. Mismatch distribution analysis for the two genetic lineages (western Black Sea and eastern Black Sea populations) of Myodes glareolus in Turkey using combined data.
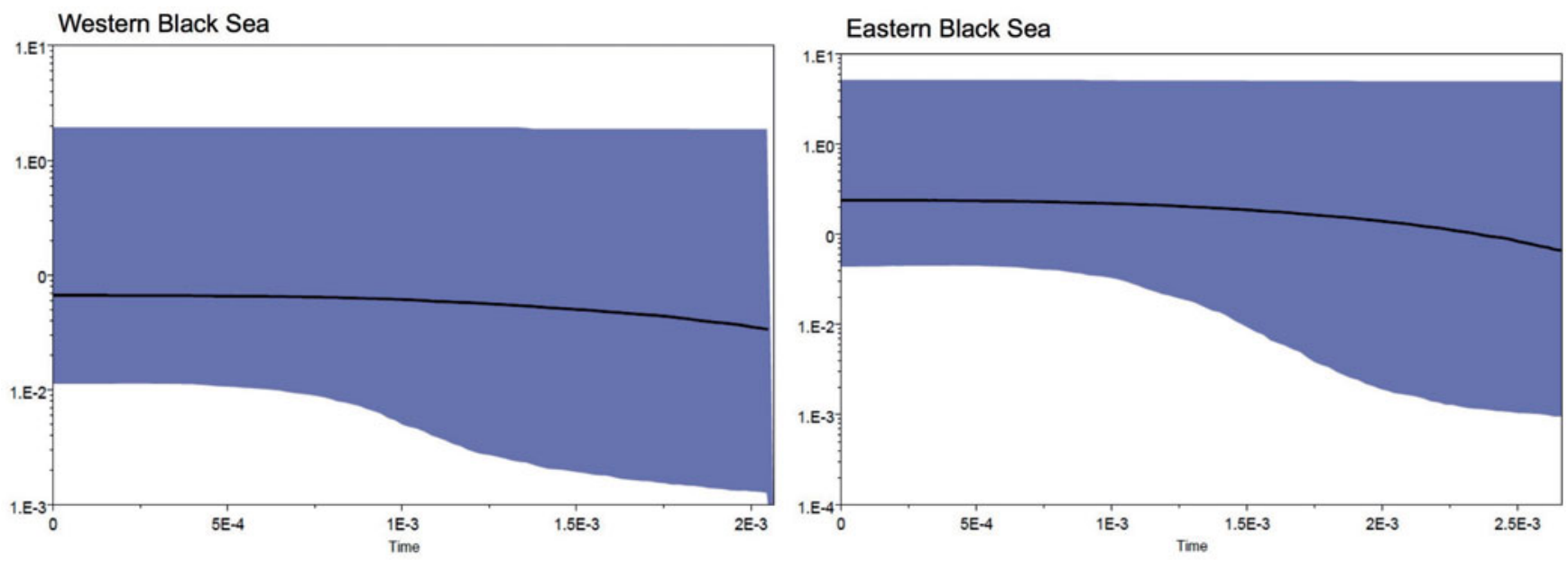

Figure 4. Bayesian skyline plots for major mtDNA clades of Myodes glareolus. The thick line is the median estimated population size and the shaded areas are the $95 \%$ confidence interval. The y-axis is logarithmic.

95\% confidence interval (CI) of the time of separation was calculated as: 0.36 Mya between the western and eastern Black Sea lineages, 0.53 Mya between the Turkish and European lineages.

\section{Discussion}

\section{Regional variations in Turkey}

The phylogenetic analyses obtained in this study indicate the existence of two lineages of bank vole in Turkey. The first lineage (the western Black Sea lineage) comprises specimens from Sile, Kandira, Akcakoca, Abant, Zonguldak, Kizilcahamam, Kure, Burnuk and Goktepe. The second one (the eastern Black Sea lineage) corresponds to populations of Cakalli, Gurgentepe, Ulubey, Unye, Bicik, Bulancak, Borcka, and Sumela (Figure 1). These results are in agreement with those obtained previously using a RAPD DNA method (Betes et al., 2014). In addition, the existence of regional variations in the Black Sea region is also supported by the genetic and morphometric studies on edible dormouse (Glis) populations living in the Black Sea forests (Helvaci et al., 2012, Selcuk et al., 2012). In their study on tree frogs, Gvozdik et al., (2010) also revealed that northwestern Turkey might have functioned as an alternative refuge. Furthermore, it is demonstrated that different micro refuge areas exist in the Black Sea region (Fritz et al., 2009).
These regional variations can be attributed to differences in the following environmental factors:

Pollen records confirmed that deciduous trees species, corresponding to the main habitats for bank voles, were present in Turkey during the Pleistocene period (Hewitt, 1996). However, these deciduous forests were probably frequently fragmented during the different ice ages, which characterized the Quaternary period (Deffontaine et al., 2005). The molecular clock analyses conducted in this study indicated that the eastern and western Black Sea lineages differentiated during the Pleistocene period (0.36 Mya). This differentiation would be therefore associated to the deciduous forest fragmentations, which appeared during the last cold periods of the Quaternary. As mentioned in the studies of Gerlach \& Musolf (2000), and Haapakoski \& Ylonen (2010), the constraints on mating and foraging behaviors resulted by habitat fragmentations. Thus, this fragmentation might have led to variations of the bank vole populations distributed throughout the Black Sea region also.

Fossil records indicated that bank vole was widely distributed until the Taurus Mountains during the mid-Pleistocene period (Montiure et al., 1994). Although bank vole does not currently live in Thrace forests, mid-Pleistocene fossil records have been identified in Yarımburgaz Cave (Santel \& Von Koenigswald, 1998). A central Anatolian lake was reported to have broken up the region during the mid-Pleistocene period, with a remaining 


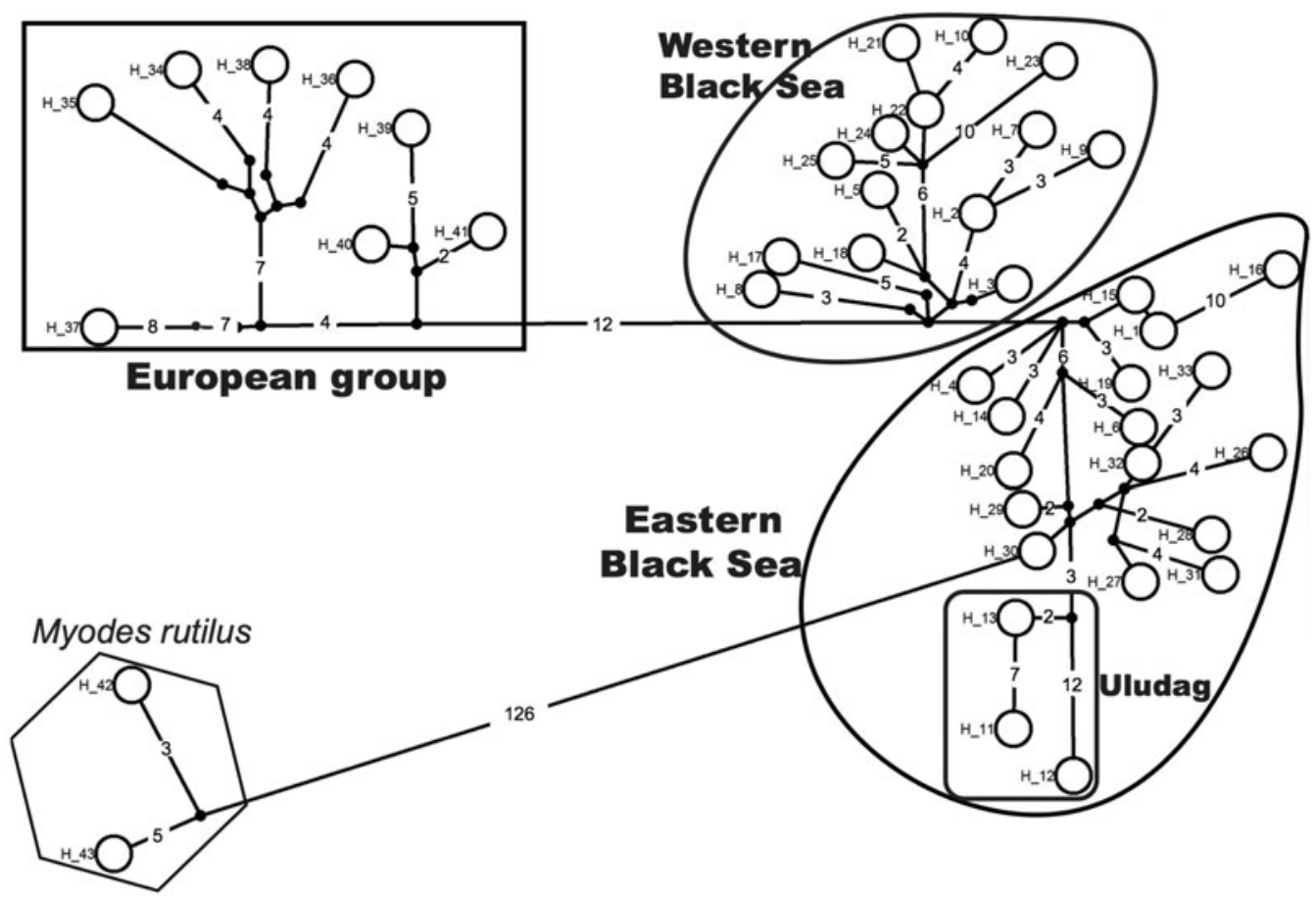

Figure 5. Median-joining network obtained using the bank voles mtDNA (cytb and D-loop) haplotypes. Numbers of mutations (greater than one) between haplotypes are indicated on branches. See supplementary material for the haplotype designations.

Table 2. AMOVA of mtDNA composite haplotypes inferred from cytb and D-loop among M. glareolus groups in Turkey.

\begin{tabular}{lrrcc}
\hline Source of variation & D.F.* & $\begin{array}{r}\text { Sum of } \\
\text { squares }\end{array}$ & $\begin{array}{c}\text { Variance } \\
\text { components }\end{array}$ & $\begin{array}{c}\text { Percentage of } \\
\text { variation }\end{array}$ \\
\hline Among groups & 1 & 50.288 & 3.05792 & 35.99 \\
Within groups & 31 & 168.591 & 5.43842 & 64.01 \\
Total & 32 & 218.879 & 8.49633 & \\
Fixation index $\mathrm{F}_{\mathrm{ST}}=0.35991$ & & & \\
\hline
\end{tabular}

*D.F. $=$ Degrees of freedom.

narrow land bridge in the Sinop region (Demirsoy, 2002). The findings of this study revealed that two different groups of Black Sea populations exist, one in the east and the other one west of Sinop. This strongly suggests the possible barrier effect of the central Anatolian lake in this region.

The Kizilirmak Delta is formed between Sinop and Samsun, where Kizilırmak, the longest river in Turkey, flows into the Black Sea. Quaternary tectonic activities and changes in the sea level during glacial or interglacial periods have contributed to the delta formation during Holocene (Turoğlu, 2010). The Kizılırmak Delta might have interrupted its continuity of forest habitats extending throughout the Black Sea region and this would have led to a forest habitat fragmentation that restricted gene flow among populations.

In terms of topography, the mountain range in northern Anatolia has a westward direction and starts to ascend towards the east after Kızılırmak Delta (for example, while Küre Mountains reach as high as $1300 \mathrm{~m}$, the Rize Mountains reach a height of up to $3500 \mathrm{~m}$ ). Furthermore, it is reported that eastern Black Sea Mountains have almost totally undergone Pleistocene glaciations (Çiner, 2003). The populations living in the wide mountain blocks of the region might have been affected by a genetic bottleneck (Hewitt, 1996, 1999, 2004). The poorer haplotype diversity in the eastern Black Sea group compared to their western counterpart observed in our study supports the existence of a genetic bottleneck in this region (Tables 1).

\section{Similarity between Uludag and eastern Black Sea bank vole populations}

Aside from the eastern Black Sea, some other high altitude regions of Anatolia have also undergone late Quaternary glaciations, although they do not have glaciers at present (Çiner, 2003). One of these mountains is Uludag, located southeast of Bursa $(2543 \mathrm{~m})$. In this study, the eastern Black Sea and Uludag lineages are clustered together in contrast to that given by (Deffontaine et al., 2009, Deffontaine et al., 2005), as the Uludag and Balkan lineages formed a clade. There may be two possible reasons for this interesting case: (1) These two groups live at similar altitudes and ecological conditions. The same haplotypes might be selected due to these similar ecological conditions by natural selection pressure for these two groups. (2) Uludag seems to be an isolated habitat for $M$. glareolus. Isolated habitats cause a genetic bottleneck that decreases genetic diversity, and the haplotypes were selected randomly by genetic drift. These randomly selected haplotypes might group the Uludag group with the northeastern Black Sea lineage by chance.

\section{Similarity between the Balkans and Turkey}

The phylogenetic tree and network generated by the $c y t b$ analyses indicated that the Balkan lineage seems closely related to the Turkish groups. The similarity between these two lineages, which are distributed in the two geographical regions connected with the Marmara Strait, is an expected pattern. The gene exchange between the Balkan and Anatolian populations might have started with the decreasing of the sea level in Marmara, which led to the appearance of land bridges between the two regions during the Pleistocene glaciations. Genetic similarity between the Balkan and Anatolian populations has also been demonstrated by the studies on the wood mouse Apodemus sylvaticus 
(Michaux et al., 2003). On the other hand, the molecular clock analyses employed in this study indicated that the Anatolian and Balkan groups diverged 0.39 Mya. This differentiation might be attributed to the opening of the Marmara Strait, with increasing temperatures that resulted in the interruption of contacts between populations.

\section{Diversity between European and Turkish groups}

The topologies of the European groups in MP and ML tree produced the same topology with the lineages in Deffontaine et al. (2005) while the NJ tree was different. Also, these three topologies were highly different with Filipi et al. (2015). In addition, in the previous studies Italian-Spanish group was formed a clade with Balkan group (Deffontaine et al., 2005, Filipi et al., 2015), Balkan lineages was closer to Turkish group while the Italian-Spanish lineages was the base of these clade in this study.

Divergence time estimations depend on combined data Europe phylogroups and Turkish groups dates back to $0.53 \mathrm{Mya}$. This is an earlier date than the formation of the genetic variation between the Balkan phylogroup and Turkish groups. According to Michaux et al. (2003, 2004), the refuge in the Balkans blocked the distribution of genomes coming from the Black Sea. Hewitt (1999) also claims that more northern neighbors blocked the Turkish genomes and the populations formed isolated refuges. The findings of this study are in accordance with the findings of both researchers.

\section{Conclusion}

The populations in southern refuges experienced regional restriction and distribution during Pleistocene glaciations. Turkey is one of these glacial period refuges that have been a biotope for the temperate species. Similar to European refuges, Turkey has internal regional variations, too. These regional variations are particularly effective on species influenced by small-scale habitat fragmentations, such as $M$. glareolus populations. The findings of the study revealed that $M$. glareolus populations distributed throughout the northern Anatolia region demonstrated variations in eastern and western directions, separated by the Kizilırmak Valley. This separation would be explained by the presence of a central Anatolian lake during the mid-Pleistocene, which would have broken up the region and would have led to the appearance of two different $M$. glareolus genetic lineages.

\section{Acknowledgements}

Thank Lisa Ann Meredith for language editing.

\section{Declaration of interest}

This study was sponsored by the Scientific Research Projects Office of the Ankara University-BAPRO (Project: 09B4240001).

\section{References}

Avise JC. (2000). Phylogeography: The history and formation of species. London, England: Harvard University Press.

Bandelt HJ, Forster P, Rohl A. (1999). Median-joining networks for inferring intraspecific phylogenies. Mol Biol Evol 16:37-48.

Betes D, Çolak R, Karacan GO, Kandemir I, Kankilic T, Çolak E. (2014). Population genetic variability of Myodes glareolus (Schreber, 1780) (Mammalia: Rodentia) distributed in northern Anatolia as revealed by RAPD-PCR analysis. Acta Zoologica Bulgarica 66:31-7.

Bilgin R. (2011). Back to the suture: The distribution of intraspecific genetic diversity in and around Anatolia. Int J Mol Sci 12:4080-103.

Brown WM, George M JR., Wilson AC. (1979). Rapid evolution of animal mitochondrial DNA. Proc Natl Acad Sci U S A 76:1967-71.
Ciplak B. (2004). Systematics, phylogeny and biogeography of Anterastes (Orthoptera, Tettigoniidae, Tettigoniinae): Evolution within a refugium. Zool Scr 33:19-44.

Çiner A. (2003). Recent glaciers and late quaternary glacial deposits of Turkey. Geol Bull Turk 46:55-78.

Çolak E, Kivanç E. (1991). Distribution and taxonomic status of genus Clethrionomys (Tiselius, 1850) (Mammalia: Rodentia) in north Anatolia. Commun Fac Univ Ank 9:1-16.

Çolak E, Yiğit N, Özkurt Ş, Sözen M. (1997). Karyotype of Clethrionomys glareolus (Schreber, 1780) (Mammalia: Rodentia) in Turkey. Turk J Zool 21:123-5.

Deffontaine V, Ledevin R, Fontaine MC, Quere JP, Renaud S, Libois R, Michaux JR. (2009). A relict bank vole lineage highlights the biogeographic history of the Pyrenean region in Europe. Mol Ecol 18:2489-502.

Deffontaine V, Libois R, Kotlik P, Sommer R, Nieberding C, Paradis E, Searle JB, Michaux JR. (2005). Beyond the Mediterranean peninsulas: Evidence of central European glacial refugia for a temperate forest mammal species, the bank vole (Clethrionomys glareolus). Mol Ecol 14:1727-39.

Demirsoy A. 2002. Genel zoocoğrafya ve türkiye zoocoğrafyası. Ankara, Turkey: meteksan.

Doyle JJ, Doyle JL. (1991). Isolation of plant DNA from fresh tissue. Focus 12:13-15.

Drummond AJ, Suchard MA, Xie D, Rambaut A. (2012). Bayesian phylogenetics with BEAUti and the BEAST 1.7. Mol Biol Evol 29: 1969-73.

Excoffier L, Lischer HE. (2010). Arlequin suite ver 3.5: A new series of programs to perform population genetics analyses under Linux and Windows. Mol Ecol Resour 10:564-7.

Felsenstein J. (1985). Confidence-limits on phylogenies - An approach using the bootstrap. Evolution 39:783-91.

Felten H, Spitzenberger F, Storch G. (1971). Zurkleinsaugerfauna westAnatoliens. Senckenb Biologica 52:393-424.

Filipi K, Marková S, Searle JB, Kotlík P. (2015). Mitogenomic phylogenetics of the bank vole Clethrionomys glareolus, a model system for studying end-glacial colonization of Europe. Mol Phylogenet Evol 82:245-57.

Fritz U, Ayaz D, Hundsdorfer AK, Kotenko T, Guicking D, Wink M, Tok CV, et al. (2009). Mitochondrial diversity of European pond turtles (Emys orbicularis) in Anatolia and the Ponto-Caspian Region: Multiple old refuges, hotspot of extant diversification and critically endangered endemics. Org Divers Evol 9:100-14.

Fu YX. (1997). Statistical tests of neutrality of mutations against population growth, hitchhiking and background selection. Genetics 147:915-25.

Gerlach G, Musolf K. (2000). Fragmentation of landscape as a cause for genetic subdivision in bank voles. Conserv Biol 14:1066-74.

Gvozdik V, Moravec J, Klutsch C, Kotlik P. (2010). Phylogeography of the Middle Eastern tree frogs (Hyla, Hylidae, Amphibia) as inferred from nuclear and mitochondrial DNA variation, with a description of a new species. Mol Phylogenet Evol 55:1146-66.

Haapakoski M, Ylonen H. (2010). Effects of fragmented breeding habitat and resource distribution on behavior and survival of the bank vole (Myodes glareolus). Popul Ecol 52:427-35.

Hall TA. (1999). BioEdit: A user-friendly biological sequence alignment, editor and analysis program for Windows 95/98/NT. Nucleic Acids Symp Ser 41:95-8.

Helvaci Z, Renaud S, Ledevin R, Adriaens D, Michaux J, Colak R, Kankilic T, et al. (2012). Morphometric and genetic structure of the edible dormouse (Glis glis): A consequence of forest fragmentation in Turkey. Biol J Linn Soc 107:611-23.

Hewitt GM. (1996). Some genetic consequences of ice ages, and their role in divergence and speciation. Biol J Linn Soc 58:247-76.

Hewitt GM. (1999). Post-glacial re-colonization of European biota. Biol J Linn Soc 68:87-112.

Hewitt GM. (2000). The genetic legacy of the quaternary ice ages. Nature 405:907-13.

Hewitt GM. (2004). The structure of biodiversity - Insights from molecular phylogeography. Front Zool 1:4.

Huelsenbeck JP, Ronquist F. (2001). MRBAYES: Bayesian inference of phylogenetic trees. Bioinformatics 17:754-5.

Kimura M. (1980). A simple method for estimating evolutionary rates of base substitutions through comparative studies of nucleotide sequences. J Mol Evol 16:111-20. 
Irwin DM, Kocher TD, Wilson AC. (1991). Evolution of the cytochromeB gene of mammals. J Mol Evol 32:128-44.

Kotlik P, Deffontaine V, Mascheretti S, Zima J, Michaux JR, Searle JB. (2006). A northern glacial refugium for bank voles (Clethrionomys glareolus). Proc Natl Acad Sci USA 103:14860-4.

Krystufek B, Vohralik V. (2005). Mammals of Turkey and Cyprus. Rodentia I: Sciuridae, Dipodidae, Gliridae, Arvicolinae: Knjiznica Annales Majora. Koper: University of Primorska, Science and Research Centre.

Larkin MA, Blackshields G, Brown NP, Chenna R, Mcgettigan PA, Mcwilliam H, Valentin F, et al. (2007). Clustal W and Clustal X version 2.0. Bioinformatics 23:2947-8.

Lebedev VS, Bannikova AA, Tesakov AS, Abramson NI. (2007). Molecular phylogeny of the genus Alticola (Cricetiidae, Rodentia) as inferred from the sequence of the cytochrome b gene. Zool Scr 36: 547-63.

Matson CW, Baker RJ. (2001). DNA sequence variation in the mitochondrial control region of red-backed voles (Clethrionomys). Mol Biol Evol 18:1494-501.

Michaux JR, Bellinvia A, Lymberakis P. (2005). Taxonomy, evolutionary history and biogeography of the broad-toothed field mouse (Apodemus mystacinus) in the eastern Mediterranean area based on mitochondrial and nuclear genes. Biol J Linn Soc 85: 53-63.

Michaux JR, Filippucci M-G, Libois R. (2004). Phylo-geographic history of the yellow-necked fieldmouse (Apodemus flavicollis) in Europe and in the Near and Middle East. Mol Phylogenet Evol 32: 188-98.

Michaux JR, Magnanou E, Paradis E, Nieberding C, Libois R. (2003). Mitochondrial phylogeography of the Woodmouse (Apodemus sylvaticus) in the western Palearctic region. Mol Ecol 12:685-97.
Montiure S, Sen Ş, Michaux J. (1994). The Middle Pleistocene mammalian fauna from Emirkaya-2, Central Anatolia (Turkey): Systematics and paleoenvironment. Neues Jahrb Geol P-a 193:107-44.

Neuhauser G. (1936). Die muriden von kleinasien. Z Saugetierkd 11: $161-236$.

Osborn DJ. (1962). Rodents of the subfamily Microtinae from Turkey. J Mammal 43:515-29.

Posada D, Crandall KA. (1998). Modeltest: Testing the model of DNA substitution. Bioinformatics 14:817-18.

Rambaut A. (2012). FigTree version 1.4. Available at: http://tree.bio.ed.ac.uk/software/figtree/

Rambaut A, Suchard MA, Drummond AJ. (2013). Tracer, Version 1.6 Available at: http://tree.bio.ed.ac.uk/software/tracer/

Rozas J. (2009). DNA sequence polymorphism analysis using DnaSP. Methods Mol Biol 537:337-50.

Santel W, Von Koenigswald W. (1998). Preliminary report on the middle Pleistocene small mammal fauna from Yarimburgaz Cave in Turkish Thrace. Eiszeitalt Ggw 48:162-9.

Selcuk SE, Colak R, Karacan GO, Colak E. (2012). Population structure of edible dormouse, Glis glis (Linnaeus, 1766) in Turkey, inferred from RAPD-PCR. Acta Zool Bulg 64:77-83.

Taberlet P, Fumagalli L, Wust-Saucy AG, Cosson JF. (1998). Comparative phylogeography and postglacial colonization routes in Europe. Mol Ecol 7:453-64.

Tajima F. (1989). The effect of change in population-size on DNA polymorphism. Genetics 123:597-601.

Tamura K, Stecher G, Peterson D, Filipski A, Kumar S. (2013). MEGA6: Molecular evolutionary genetics analysis version 6.0. Mol Biol Evol, 30:2725-9.

Turoğlu H. (2010). Geomorphological characteristics of Kizılırmak delta and immediate environment and their impact on human live. Istanbul University, Faculty of Letters, Anatolian Researches 19:99-111. 